\title{
PENERAPAN SISTEM INFORMASI DALAM PRAKTEK LAPORAN KEUANGAN SEDERHANA
}

\author{
Sugiantina
}

Fakultas MIPA

Universitas Pesantren Tinggi Darul Ulum

\begin{abstract}
Abstraksisi
Terkait dengan metode analisis laporan keuangan dan penerapan teknologi informasi dalam berbagai analisis keungan, hal ini merupakan suatu tolak ukur bagi kemajuan pelaporan keuangan. Terutama terhadap upaya setiap institusi bisnis, untuk menyeimbangkan perkembangan teknologi Informasi, yang selaras dengan pekembangan analisis pelaporan keuangan.

Dengan perkembangan tersebut, institusi bisnis dituntut untuk bisa lebih cepat dan kreatif dalam bekerja kususnya dalam pelaporan keuangan. Hal ini dikarenakan adanya shopware system informasi yang sudah menjadi trend, dalam dunia bisnis. Oleh sebab itu, sekarang telah menjadi trend dalam pembuatan laporan keuangan berbasis web internet hal ini dapat memberi kemudahan dalam hal financial controlling and Manajemen bagi semua lapisan level manajemen intitusi bisnis maupun secara terbuka bagi pelanggan atau masyarakat.
\end{abstract}

KeywordsI: sistem informasi, laporan keuangan, basis data, php, MySQL.

\section{PENDAHULUAN}

Terkait dengan metode analisis laporan keuangan dan penerapan teknologi informasi dalam berbagai analisis keungan, hal ini merupakan suatu tolak ukur bagi kemajuan pelaporan keuangan. Terutama terhadap upaya setiap institusi bisnis, untuk menyeimbangkan perkembangan teknologi Informasi, yang selaras dengan pekembangan analisis pelaporan keuangan. Dengan perkembangan tersebut, institusi bisnis dituntut untuk bisa lebih cepat dan kreatif dalam bekerja kususnya dalam pelaporan keuangan. Hal ini dikarenakan adanya shopware system informasi yang sudah menjadi trend, dalam dunia bisnis. Oleh sebab itu, sekarang telah menjadi trend dalam pembuatan laporan keuangan berbasis web internet hal ini dapat memberi kemudahan dalam hal financial controlling and Manajemen bagi semua lapisan level manajemen intitusi bisnis maupun secara terbuka bagi pelanggan atau masyarakat.

Berdasarkan permasalahan tersebut, yang telah di jelaskan di atas, maka dapat dirumuskan masalah (1) Bagaimana menyajikan sebuah laporan keuangan yang terintegrasi dari beberapa unit bisnis, (2) Bagaimana menyediakan sebuah laporan keuangan yang memberi kemudahan dalam hal controlling oleh setiap bagian manajemen? (3) Bagaimana menyediakan sebuah laporan keuangaan dengan mudah serta real time, dan bisa dijadikan acuan dalam pembuatan kebijakan keuangan. Adapun tujuan dari penulisan artikel ini adalah, (1) Untuk merancang sebuah Sistem Informasi keuangan berbasis web, agar dapat diakses dari setiap unit usaha, (2) Untuk membuat user account untuk masing-masing level manajemen, dan memperjelas wewenang dan batasan dalam pengolahan laporan keuangan, (3) Untuk membangun sistem pelaporan berkala yang real time serta bisa diakses setiap saat.

Dalam penulisan artikel ini metodologi penelitian yang digunakan untuk menggali data primer maupun skundair adalah metode, (1) Metode Observasi, metode ini dilakukan dengan melakukan pengamatan langsung tentang materi-materi pelaporan keuangan institusi bisnis, (2) Metode studi leterature, metode ini digunakan untuk mempelajari teori-teori laporan keuangan bisnis yang sedang trend di aplikasikan, (3) Metode interview, metode ini digunakan untuk wawancara langsung dengan staf keuangan di intitusi bisnis.

\section{TENTANG LAPORAN KEUANGAN}

Laporan keuangan adalah catatan informasi keuangan suatu perusahaan pada suatu periode akuntansi, yang dapat digunakan untuk menggambarkan kinerja institusi bisnis. Laporan keuangan merupakan bagian dari proses pelaporan keuangan. Tujuan dari dibuatnya Laporan Keuangan adalah: (1) Memberikan informasi kas mengenai posisi keuangan institusi bisnis, (2) Memberikan 
informasi keuangan mengenai hasil usaha institusi bisnis, (3) Memberikan laporan dan intepretasi kondisi dan potensi institusi bisnis.

Komponen dari Laporan Keuangan meliputi Neraca (Balance Sheet), Laporan Laba/ Rugi (Income Statement), Laporan Perubahan Modal/Equitas (Statement of Changes of Equity), Laporan Arus Kas (Statement of Cash Flow), dan Catatan Atas Laporan Keuangan (Notes of Financial Statement). Namun bagi institusi bisnis kecil dan menengah, laporan keuangan yang perlu disusun hanyalah tiga komponen saja, yaitu Neraca (Balance Sheet), Laporan Laba/ Rugi (Income Statement), dan Laporan Arus Kas (Statement of Cash Flow). Selain itu, dalam penyusunan laporan keuangan juga dikenal istilah-istilah seperti Jurnal, Posting dan Buku Besar.

Jurnal adalah alat untuk mencatat transaksi perusahaan yang dilakukan secara kronologis (berdasarkan urut waktu terjadinya) dengan menunjukkan rekening yang harus didebet dan dikredit beserta jumlah rupiah masing-masing. Setiap transaksi yang terjadi dalam perusahaan, sebelum dibukukan ke buku besar harus dicatat dahulu dalam jurnal, sehingga jurnal disebut Buku catatan pertama (Book of Original Entry). Sedangkan manfaat jurnal adalah : (1) Sebagai alat pencatatan yang dapat menggambarkan pos-pos yang terpengaruh oleh suatu transaksi, (2) Sebagai alat pencatatan yang memberi gambaran secara kronologis, (3) Sebagai jurnal yang dapat dipecah-pecah menjadi beberapa jurnal khusus yang dikerjakan oleh beberapa orang secara bersamaan, (4) Sebagai jurnal menyediakan ruang yang cukup untuk keterangan transaksi, (5) Sebagai acuan melakukan pengecekan kesalahan pencatatan, dibandingkan dengan transaksi catat langsung.

Adapun fungsi Jurnal bagi perusahaan adalah : (1) sebagai fungsi Analisis. Yaitu untuk menentukan perkiraan yang di debet dan perkiraan yang dikredit serta jumlahnya masing-masing, (2) Sebagai fungsi Pencatatan. Yaitu untuk mencatat transaksi keuangan dalam kolom debet dan kredit serta keterangan yang perlu, (3) sebagai fungsi Historis. Yaitu untuk mencatat aktivitas perusahaan secara kronologis. Sumber (http://dasar-akuntansi.blogspot.com/2009/09/jurnal-dasar-dasar-akuntansi). Untuk pengertian posting adalah proses memindahkan ayat-ayat jurnal yang telah dibuat dalam buku jurnal ke buku besar, yaitu memindahkan jumlah dalam kolom debet jurnal ke dalam sisi debet rekening dan memindahkan jumlah dalam kolom kredit jurnal ke dalam sisi kredit rekening. (http://agustin.staf.gunadarma.ac.id).

Sedangkan buku Besar adalah buku yang berisi semua rekening-rekening yang ada dalam laporan keuangan. Buku besar merupakan kumpulan rekening-rekening yang digunakan untuk menyortasi dan meringkas informasi yang telah dicatat dalam jurnal. Buku ini mencatat perubahan-perubahan yang terjadi pada masing-masing rekening dan pada akhir periode akan tampak saldo dari rekeningrekening tersebut. Setiap transaksi yang telah dicatat dalam jurnal akan diposting atau dipindahkan ke Buku Besar secara berkala. Buku besar meliputi :

\section{a. Laporan Neraca Keuangan}

Laporan Neraca (Balance Sheet) adalah daftar yang sistematis dari aktiva, utang dan modal pada periode tertentu. Disebut sebagai daftar yang sistematis, karena neraca disusun berdasarkan urutan tertentu. Dalam neraca dapat diketahui berapa jumlah kekayaan perusahaan, kemampuan perusahaan membayar kewajiban serta kemampuan perusahaan memperoleh tambahan pinjaman dari pihak luar. Selain itu juga dapat diperoleh informasi tentang jumlah utang perusahaan kepada kreditur dan jumlah investasi pemilik yang ada didalam perusahaan tersebut.

\section{b. Laporan Laba-Rugi}

Laporan Laba/ Rugi (Income Statement) adalah adalah laporan yang mengukur keberhasilan operasi perusahaan selama periode tertentu. Tujuan dibuatnya laporan ini adalah untuk mengetahui hasil kinerja operasi perusahaan, untung atau rugi. Yang disusun dalam laporan laba/ rugi adalah penjualan bersih dan biaya - yang dikeluarkan selama periode tertentu. Perusahaan dikatakan untung apabila total pendapatan lebih besar dari total biaya dan dikatakan rugi apabila total pendapatan lebih kecil dari total biaya.

Kegunaan laporan laba/ rugi adalah untuk mengevaluasi kinerja masa lalu perusahaan, memberikan dasar untuk memprediksi kinerja masa depan, dan membantu menilai resiko ketidakpastian 


\section{c. Laporan Arus Kas (Statement of Cash Flow)}

Laporan arus kas adalah laporan yang menggambarkan perjalanan kas selama periode tertentu. Tujuan utama laporan arus kas adalah menyediakan informasi yang relevan mengenai penerimaan dan pembayaran kas sebuah perusahaan selama satu periode. Donald E. Kieso, Jerry JW., dan Terry DW., dalam bukunya "Akuntansi Intermediate Edisi Kesepuluh, terjemahan Emil Salim, mengklasigikasikan Laporan Arus Kas kedalam tiga aktivitas, yaitu:

1. Aktivitas Operasi (Operating Activities)

Meliputi pengaruh kas dari transaksi operasaional untuk menentukan laba bersih.

2. Aktivitas Investasi (Investing Activities)

Meliputi pemberian dan penagihan pinjaman serta investasi.

3. Aktivitas Pembiayaan (Financing Activities)

Meliputi kewajiban dan ekuitas pemilik (http://irfunk.multiply.com/jurnal/item/30 -_ftn6, diakses pada tanggal 07 April 2010)

\section{d. Perbedaan Laporan Keuangan dan Pelaporan Keuangan}

Haruslah dibedakan antara pengertian Pelaporan keuangan (financial reporting) dan Laporan Keuangan (financial reports). Mungkin selama ini kadang memanfaatkan jasa analisa atau jasa audit mengenai keuangan. Misalnya datang ke kantor akuntan, seperti kantor akuntan publik, atau jasa keuangan lainnya. Pelaporan Keuangan meliputi segala aspek yang berkaitan dengan penyediaan dan peyampaian informasi keuangan. Aspek-aspek tersebut antara lain lembaga yang terlibat (misalnya penyusunan standar, badan pengawas dari pemerintah atau pasar modal, organisasi profesi, dan entitas pelapor), peraturan yang berlaku termasuk PABU (prinsip akuntansi berterima umum atau generally accepted accounting principles/GAAP). Laporan keuangan hanyalah salah satu medium dalam penyampaian informasi

\section{PERANCANGAN SISTEM INFORMASI UNTUK LAPORAN KEUANGAN}

\subsection{Perancangan Sistem Informasi}

Perancangan sistem informasi merupakan pengembangan sistem baru dari sistem lama yang ada, dimana masalah-masalah yang terjadi pada sistem lama diharapkan sudah teratasi pada sistem yang baru. Pada perancangan sebuah sistem, terdapat dua hal penting yang dibahas yaitu:

a. Analisis Sistem: menganalisis dan mendefinisikan masalah dan kemungkinan solusinya untuk sistem informasi dan proses organisasi.

b. Perancangan Sistem: merancang output, input, struktur file, program, prosedur, perangkat keras dan perangkat lunak yang diperlukan untuk mendukung sistem informasi.

c. Pembangunan dan Testing Sistem: membangun perangkat lunak yang diperlukan untuk mendukung sistem dan melakukan testing secara akurat. Melakukan instalasi dan testing terhadap perangkat keras dan mengoperasikan perangkat lunak.

d. Implementasi Sistem: beralih dari sistem lama ke sistem baru, melakukan pelatihan dan panduan seperlunya.

e. Operasi dan Perawatan: mendukung operasi sistem informasi dan melakukan perubahan atau tambahan fasilitas.

f. Evaluasi Sistem: mengevaluasi sejauh mana sistem telah dibangun dan seberapa bagus sistem telah dioperasikan.

Sedangkan alasan pentingnya analisis sistem informasi adalah:

a. Problem-solving: sistem lama tidak berfungsi sesuai dengan kebutuhan. Untuk itu analisis diperlukan untuk memperbaiki sistem sehingga dapat berfungsi sesuai dengan kebutuhan.

b. Kebutuhan baru: adanya kebutuhan baru dalam organisasi atau lingkungan sehingga diperlukan adanya modifikasi atau tambahan sistem informasi untuk mendukung organisasi.

c. Mengimplementasikan ide atau teknologi baru.

d. Meningkatkan performansi sistem secara keseluruhan.

\subsection{Proses Pengembangan Sistem}

\section{a. Metode Perancangan Tradisional}


Kebanyakan metodologi yang digunakan pada saat ini, adalah metodologi tradisional. Pada metode ini, terdapat 3 tahapan yang digunakan untuk proses pengembangan sistem, yaitu: (1) Analisis Kebutuhan, (2) Pemodelan Data, (3) Normalisasi.

b. Metode Perancangan Barker

Metode barker yang digunakan untuk pengembangan sistem ini, menggunakan prinsipprinsip yang sama seperti metode relasional. Ada 7 tahapan yang digunakan pada metode barker, yaitu: (1) Strategi, (2). Analisis, (3) Perancangan, (4) Pembuatan, (5) Dokumentasi, (6) Transisi, (7) Produksi.

\section{c. Metode Perancangan Adapted}

Pada metode perancangan adapted terdapat 9 tahapan yang digunakan dalam pengembangan sistem, yaitu: (1) Strategi, (2) Sebelum Analisis, (3) Analisis, (4) Sebelum Perancangan, (5) Perancangan, (6) Pembangunan, (7) Pengujian, (8) Implementasi, (9) Perawatan.

\subsection{Bahasa Pemrograman dalam Perancangan Sistem}

PHP yang dulu dikenal dengan Personal Home Page, serta dikenal dengan Hipertext Preprocessor saat ini, merupakan script untuk membuat suatu aplikasi yang dapat terintergrasikan ke dalam HTML. Sehingga suatu halaman web tidak lagi bersifat statis, namun menjadi bersifat dinamis. Secara khusus PHP dirancang untuk membentuk web dinamis. Artinya, ia dapat membentuk suatu tampilan berdasarkan permintaan terkini. Misalnya, anda bisa menampilkan isi database kehalaman web. Pada prinsipnya PHP mempunyai fungsi yang sama dengan script-script seperti ASP (Active Server Page), Cold Fusion, ataupun Perl (Dasar Pemrograman Web Dinamis Menggunakan PHP:Abdul Kadir, 2001).

Dibandingkan dengan bahasa pemrograman lainnya sebagai server side, bahasa pemrograman PHP, memiliki beberapa keunggulan sebagai berikut:

1. Source Program atau script tidak dapat dilihat dengan menggunakan fasilitas view HTML source, yang ada pada web browser, seperti Internet Explore, atau semacamnya.

2. Script tersebut dapat memanfaatkan sumber-sumber aplikasi yang dimiliki oleh server. Seperti misalnya, untuk keperluan database connection.

3. Pada aplikasi yang dibuat dengan PHP, pada saat dijalankankan, server akan mengerjakan script, dan hasilnyalah yang akan ditampilkan ke web browser.

4. PHP dapat melakukan semua program CGI, seperti mengambil nilai form, menghasilkan halaman web yang dinamis, mengirimkan dan menerima cooki. Selain itu, PHP juga bisa berkomunikasi dengan layanan-layanan yang menggunakan protokol IMAP, SNMP, POP3, HTTP dan lainnya (Memahami Pemrograman Web dengan PHP dan MySQL dalam 24 jam, Teguh Wahyono, 2005).

\subsection{Pembuatan Database Manajemen Sistem}

Basis data (database), atau sering pula dieja basis data, adalah kumpulan informasi yang disimpan di dalam komputer secara sistematik, sehingga dapat diperiksa menggunakan suatu program komputer untuk memperoleh informasi dari basis data tersebut. Perangkat lunak yang digunakan untuk mengelola dan memanggil kueri (query) basis data disebut sistem manajemen basis data (Database Manajemen Sistem, DBMS). Sistem basis data dipelajari dalam ilmu informasi.

Konsep dasar dari basis data adalah kumpulan dari catatan-catatan, atau potongan pengetahuan. Sebuah basis data memiliki penjelasan terstruktur dari jenis fakta yang tersimpan di dalamnya. Penjelasan ini disebut skema. Skema menggambarkan obyek yang diwakili suatu basis data, dan hubungan di antara obyek tersebut. Ada banyak cara untuk mengorganisasi skema, atau memodelkan struktur basis data. Hal ini dikenal sebagai model basis data atau model data. Model yang umum digunakan sekarang adalah model relasional, yang mewakili semua informasi dalam bentuk tabeltabel yang saling berhubungan. Dimana setiap tabel terdiri dari baris dan kolom.

DBMS (DataBase Manajemen Sistem) adalah sistem yang secara khusus dibuat untuk memudahkan pemakai dalam mengelola basis data. Sistem ini dibuat untuk mengatasi kelemahan sistem pemrosesan yang berbasis berkas.Pada pendekatan yang berbasis berkas, umumnya perancangan 
sistem didasarkan pada kebutuhan individual pemakai, bukan berdasarkan kebutuhan sejumlah pemakai.

Setiap kali terdapat kebutuhan baru dari seorang pemakai, kebutuhan segera diterjemahkan kedalam program komputer. Akibatnya, kemungkinan besar setiap program aplikasi menuliskan data tersendiri. Sementara itu ada kemungkinan data yang sama juga terdapat pada berkas lain yang digunakan oleh program aplikasi (http://blog.re.or.id/komponen-dbms.htm).

\section{a. Database MySQL}

MySQL adalah salah satu jenis database server yang terkenal. kepopulerannya. Hal ini disebabkan, MySQL menggunakan SQL sebagai bahasa dasar untuk mengakses databasenya. Selain itu, ia bersifat free pada berbagai platform, kecuali pada wimdows yang bersifat shareware (kita perlu membayar setelah melakukan evaluasi, dan memutuskan untuk digunakan sebagai keperluan produksi). Perangkat lunak MySQL sendiri dapat didownload dari: http://www.mysql.com.

MySQL sendiri termasuk jenis RDBMS (Relational Database Management System). Itulah sebabnya, istilah baris, kolom dan table digunakan pada MySQL. Pada MySQL, sebuah database mengandung satu atau sejumlah table. Table terdiri atas sejumlah baris, dan setiap baris terdiri dari satu atau beberapa kolom(Dasar Pemrograman Web Dinamis Menggunakan PHP:Abdul Kadir :2001).

\section{b. Use Case Diagram}

Use case diagram adalah gambaran graphical dari beberapa atau semua actor, use case, dan interaksi diantara komponen-komponen tersebut, yang memperkenalkan suatu sistem yang akan dibangun. Use case diagram menjelaskan manfaat suatu sistem jika dilihat menurut pandangan orang yang berada di luar sistem. Diagram ini menunjukkan fungsionalitas suatu sistem atau kelas dan bagaimana sistem tersebut berinteraksi dengan dunia luar (http://adboclass.files.wordpress.com/2010/03/modul).

Ada tiga komponen pokok dalam use case yaitu: (1) Aktor : Aktor pada use case diagram digunakan untuk mempresentasikan seseorang atau sesuatu (seperti perangkat, sistem lain) yang berinteraksi dengan sistem. (2) Use case: Use case adalah gambaran fungsionalitas dari suatu sistem, sehingga customer atau pengguna sistem paham dan mengerti mengenai kegunaan sistem yang akan dibangun. Selain itu, use case diagram merupakan penggambaran sistem dari sudut pandang pengguna sistem tersebut (user), sehingga pembuatan use case lebih dititikberatkan pada fungsionalitas yang ada pada sistem, bukan berdasarkan alur atau urutan kejadian. (3) Relasi / Hubungan : Selain aktor dan use case, satu komponen penting lagi dalam use case diagram adalah relasi. Ada beberapa relasi yang terdapat pada use case di

\section{c. Data Flow Diagram (DFD)}

Data Flow Diagram atau dikenal dengan Diagram Alur Data merupakan alat yang cukup populer sekarang, karena dapat menggambarkan arus data di dalam suatu sistem dengan terstruktur dan jelas, itulah sebabnya DFD merupakan alat bantu yang paling penting bagi seorang analis system.

DFD dapat merepresentasikan suatu sistem yang otomatis maupun manual dengan menggunakan gambar yang berbentuk jaringan grafik. Adapun beberapa simbol yang digunakan dalam penggambaran DFD, yaitu :

1. Entitas Luar (External Entity) dan Terminal

Entitas Luar adalah entitas yang berada di luar sistem yang memberikan data kepada sistem (source) atau yang menerima informasi dari sistem (sink). Entitas Luar ini bukanlah bagian dari sistem, bila suatu sistem informasi dirancang untuk satu bagian/departemen maka bagian lain yang masih terkait menjadi entitas luar. Sedangkan terminal adalah entitas yang merupakan bagian dari sistem. Simbol yang digunakan berbentuk kotak.

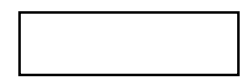


Gambar 3.1: Simbol untuk entitas pada DFD.

2. Proses

Proses menggambarkan apa yang dilakukan oleh sistem. Berfungsi mentransformasikan satu atau beberapa data masukan menjadi satu atau beberapa data keluaran sesuai dengan spesifikasi yang diinginkan. Setiap proses memiliki satu atau beberapa data masukan serta menghasilkan satu atau beberapa data keluaran. Proses sering pula disebut bubble. Simbol untuk proses berbentuk lingkaran.

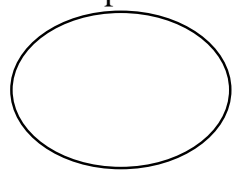

Gambar 3.2: Simbol untuk proses pada DFD

3. Data Flow

Data Flow atau Alir Data menggambarkan aliran data dari suatu entitas ke entitas lainnya. Arah panah menggambarkan aliran data. Ada beberapa aliran data, yaitu :

- Antara dua proses yang berurutan.

- Dari penyimpanan data (data store) ke proses dan sebaliknya.

- Dari source ke proses.

- Dari proses ke link.

4. Data Store

Data store adalah tempat menyimpan data. Proses dapat mengambil data dari atau memberikan data ke data store

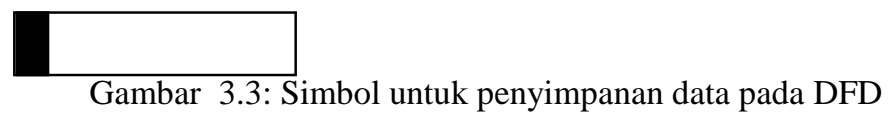

\section{d. Entity Relationship Diagram (ERD)}

ERD merupakan suatu model untuk menjelaskan hubungan antar data dalam basis data berdasarkan objek-objek dasar data yang mempunyai hubungan antar relasi. Selain itu, ERD juga digunakan untuk memodelkan struktur data dan hubungan antar data, untuk menggambarkannya digunakan beberapa notasi dan simbol (http://blog.re.or.id, diakses pada tanggal 29 maret 2010).

Pada dasarnya ada tiga simbol yang digunakan pada ERD, yaitu :

4. Entity atau Entitas

Entity/ Entitas merupakan objek yang mewakili sesuatu yang nyata dan dapat dibedakan dari sesuatu yang lain (Fathansyah, 1999: 30). Simbol dari entity ini biasanya digambarkan dengan persegi panjang.

5. Atribut

Setiap entitas pasti mempunyai elemen yang disebut atribut yang berfungsi untuk mendeskripsikan karakteristik dari entitas tersebut.

Isi dari atribut mempunyai sesuatu yang dapat mengidentifikasikan isi elemen satu dengan yang lain. Gambar atribut diwakili oleh simbol elips.

3. Relasi

Relasi merupakan hubungan antara sejumlah entitas yang berasal dari himpunan entitas yang berbeda. Adapun jenis relasi yang terdapat dalam ERD adalah : (1) Satu ke Satu (One to One), (2) Satu ke Banyak (One to Many), (3) Banyak ke Banyak (Many to Many)

\section{e. Flow Chart}

Flow chart adalah suatu bagan yang menggambarkan langkah-langkah penyelesaian dari suatu masalah, dan merupakan cara penyajian dari suatu algoritma. Tujuan membuat flow chart adalah untuk menggambarkan suatu tahapan penyelesaian masalah, secara sederhana, terurai, rapi dan jelas dengan menggunakan simbol-simbol standar.

Dalam penulisan flow chart dikenal dua model, yaitu: 
1. Sistem Flow Chart

Yaitu : bagan yang memperlihatkan urutan prosedure dan proses dari beberapa file di dalam media tertentu. Melalui flow chart ini terlihat jenis media penyimpanan yang dipakai dalam pengolahan data, selain itu juga menggambarkan file yang dipakai sebagai input dan output. Sistem flow chart juga tidak digunakan untuk menggambarkan urutan langkah untuk memecahkan masalah. Dan sistem flow chart hanya digunakan untuk menggambarkan prosedur dalam sistem yang dibentuk.

2. Program Flow Chart

Yaitu: Bagan yang memperlihatkan urutan dan hubungan proses dalam suatu program. Dua jenis metode penggambaran program flow chart adalah :

1). Conceptual flow chart, menggambarkan alur pemecahan masalah secara global.

2). Detail flow chart, menggambarkan alur pemecahan masalah secara rinci.

\section{DESAIN SISTEM LAPORAN KEUANGAN SEDERHANA}

\subsection{Use Case Diagram}

Berdasarkan analisa kebutuhan yang ada, maka alur dari pemanfaatan sistem yang baru, dapat digambarkan dengan use case sebagai berikut:

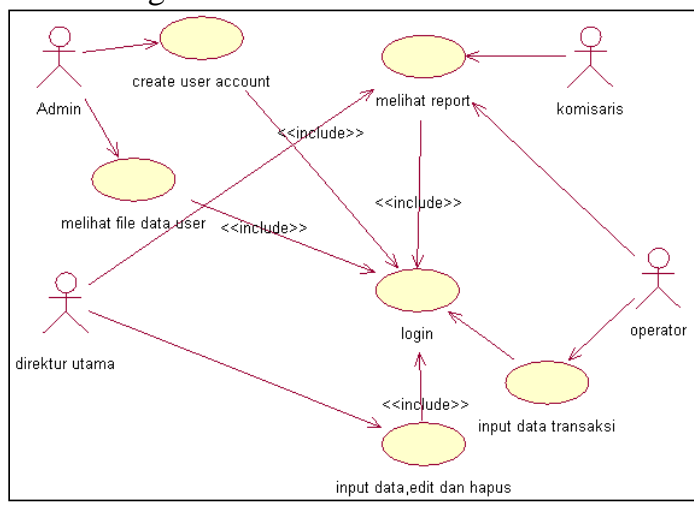

Gambar 4.1: Use Case Diagram

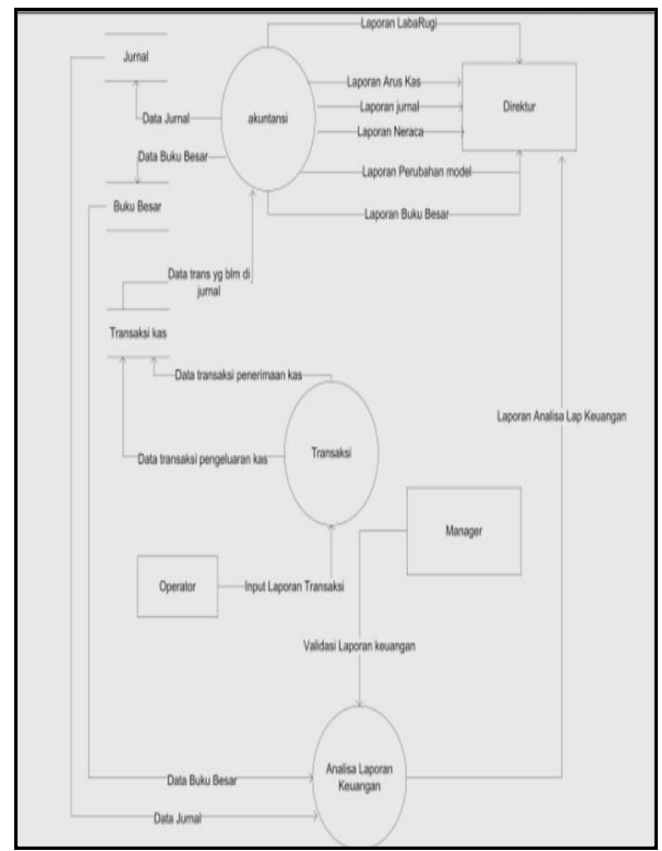

Dari use case di atas, dapat diketahui proses entry data, ataupun aktifitas yang bisa dilakukan pada sistem yang baru, yang terdiri dari :

1. Pembuatan User Account oleh Administrator.

2. Log in oleh Direktur Utama, untuk entry Data Master. 
3. Log in oleh Operator, untuk entry Data Transaksi. Sebagai bahan pembuatan laporan keuangan.

4. Log in oleh Komisaris, untuk melihat Laporan.

\subsection{Context Diagram}

Desain DFD pada Analisa Laporan Keuangan pada C.V Karya Inti Sukses ini, dimulai dari Context Diagram, seperti yanga ada di bawah ini:

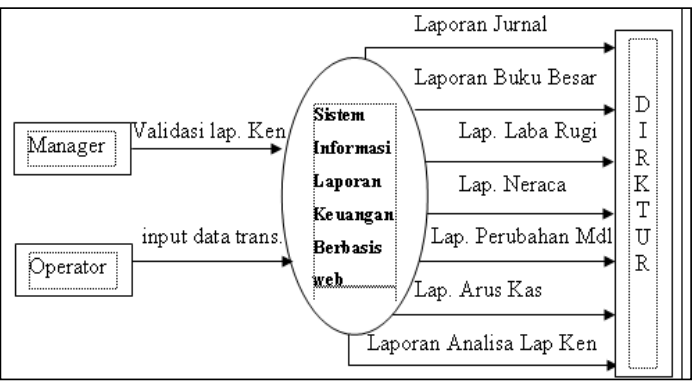

\section{Gambar 4.2: Context Diagram}

\subsection{DFD Level 0 DAN DFD Level 1}

DFD level 0 pada sistem ini menjelaskan bahwa Sistem Informasi Akuntansi dan Laporan Keuangan pada C.V Karya Inti Sukses Jombang mencakup 3 sub sistem, yaitu : akuntansi, transaksi dan analisa laporan keuangan. Sistem akuntansi berhubungan dengan pembuatan jurnal dan buku besar. Sedangkan sistem transaksi berhubungan dengan penerimaan dan pengeluaran kas perusahaan. Dan sistem laporan keuangan berhubungan dengan analisa hasil laporan keuangan. Di bawah ini adalah gambar DFD Level 0 :

Gambar 4.3: Data Flow Diagram Level 0

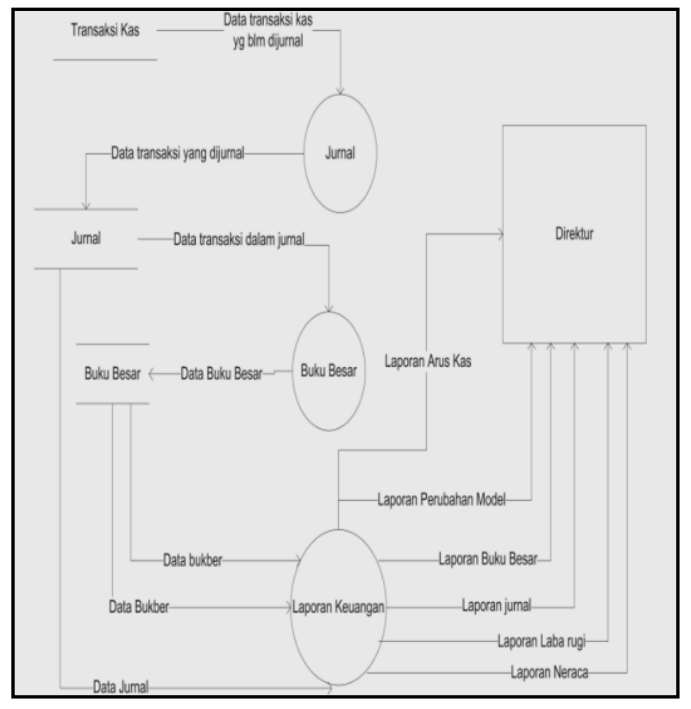

Gambar 4.4: Data Flow Diagram Level 1

Dari gambar di atas, dapat dilihat bahwa DFD level 1 terdiri dari 3 subproses sistem. Yaitu : membuat jurnal, posting ke buku besar, dan membuat laporan keuangan. Proses pembuatan jurnal, berawal dari data transaksi yang diterima, kemudian data tersebut dimasukkan dalam jurnal yang ada. Baru setelah semua data tersimpan proses yang selanjutnya adalah posting data ke buku besar. Setelah itu, data yang masuk akan diseleksi. Lalu proses laporan keuangan dibuat berdasarkan data yang diperoleh dari buku besar.

\subsection{ER/ Diagram}

Berdasarkan DFD di atas maka dapat dibuat ERD dari Sistem Informasi Laporan Keuangan. Dimana pada ERD terdapat beberapa entitas yang digunakan. Entitas tersebut terdiri dari : User, Transaksi Jurnal, dan Buku Besar. Dengan rincian:

a. Hubungan antara Entitas User dan Entitas Transaksi yaitu one to many.

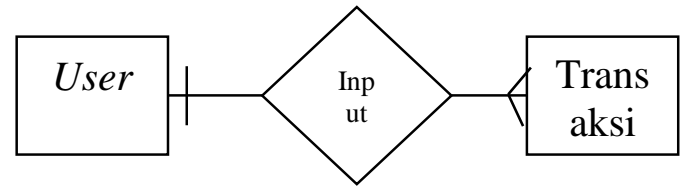


Gambar 4.5: Gambar relasi antara Entitas User dan Entitas Transaksi

b. Hubungan antara Entitas Transaksi dan Entitas Jurnal adalah one to many.

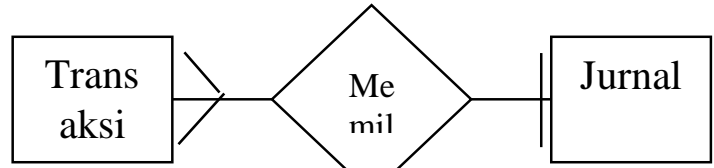

Gambar 4.0. Gambar relasi antara Entitas Transaksi dan Entitas Jurnal

c. Hubungan antara Entitas User dengan Entitas Jabatan adalah one to one.

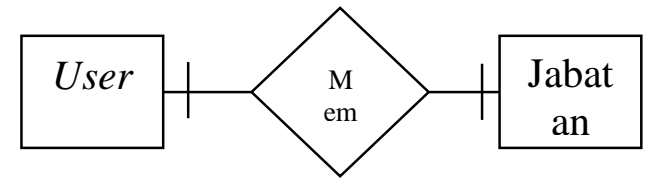

Gambar 4.7: Gambar relasi antara Entitas User dan Entitas Jabatan

d. Hubungan amtara Entitas User dan Entitas Cabang adalah one to one.

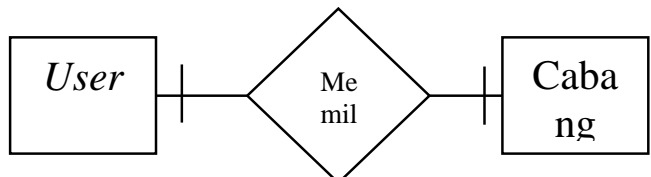

Gambar 4.8: Gambar relasi antara Entitas User dan Entitas Jabatan

e. Hubungan antara Entitas Cabang dan Entitas Laporan Rugi Laba adalah one

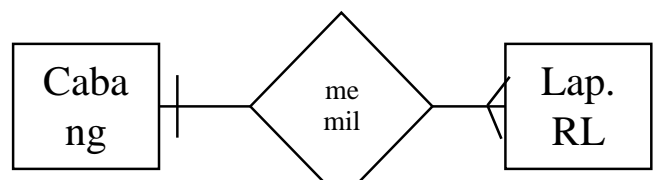

Gambar 4.9: Gambar relasi antara Entitas Cabang dan Entitas Laporan Rugi Laba.

Secara keseluruhan Entity Relationship Diagram, dapat digambarkan seperti di bawah ini:

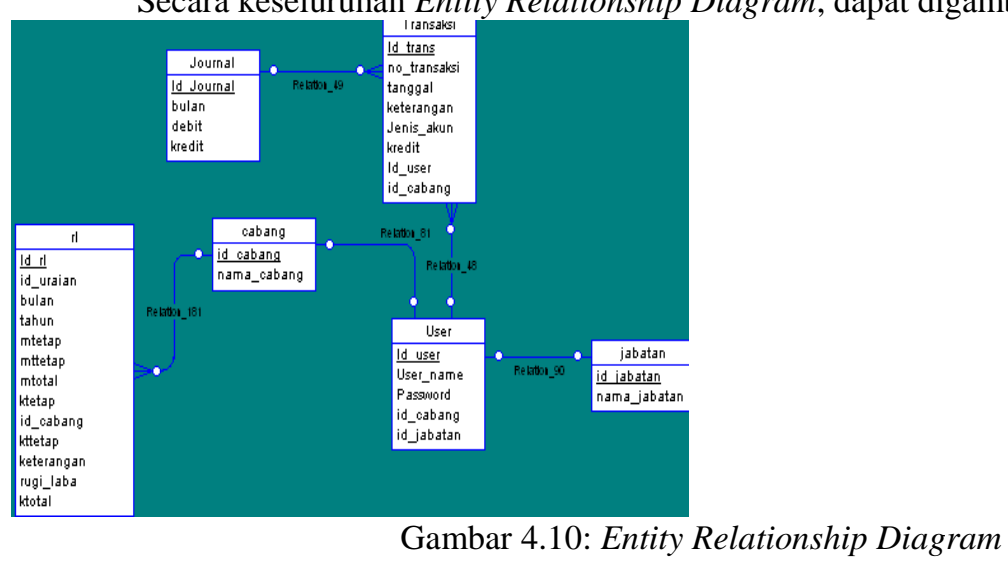

\section{DESAIN DATA LAPORAN KEUANGAN}

Setelah diketahui rancangan dari sistem yang akan dibuat, selanjutnya perlu diketahui desain data untuk rancangan pembuatan sistem yang baru, dengan tetap mengacu pada ERD yang telah dibuat. Adapun data yang akan dibuat pada rancanga sistem kali ini terdiri dari beberapa tabel dengan field dan tipe data yang berbeda, dan disesuaikan dengan kebutuhan sistem. Dibawah ini adalah desain data untuk rancangan pembuatan sistem yang baru: 
a. Tabel User

Isi dari tabel ini adalah : Id User, User Name, Password dan Id Jabatan.

Tabel 1: Tabel User

\begin{tabular}{|c|c|c|}
\hline \multicolumn{1}{|c|}{ Field } & Type & Extra \\
\hline Id_user $^{*}$ & Integer (11) & Primary key \\
Username & Varchar (64) & \\
Password & Varchar (10) & \\
Id_jabatan & Integer (11) & Foreign key \\
\hline
\end{tabular}

b. Tabel Jabatan

Tabel jabatan ini, berisi keterangan tentang jabatan dari masing-masing user. Adapun jabatan-jabatan terebut, adalah: Komisaris, Direktur/ Manager Keuangan, Admin, dan Operator.

Tabel 2: Tabel Jabatan

\begin{tabular}{|l|l|l|}
\hline \multicolumn{1}{|c|}{ Field } & \multicolumn{1}{|c|}{ Type } & \multicolumn{1}{c|}{ Extra } \\
\hline Id_jbtn* & Integer (11) & Primary \\
Nama_jabatan & Varchar (64) & key \\
\hline
\end{tabular}

c. Tabel Cabang

Tabel yang ke-3 adalah tabel cabang, yang fielnya terdiri dari : Id Cabang dan Nama Cabang.

Tabel 3: Tabel Cabang

\begin{tabular}{|l|l|l|}
\hline \multicolumn{1}{|c|}{ Field } & \multicolumn{1}{c|}{ Type } & \multicolumn{1}{c|}{ Extra } \\
\hline Id_cabang & Integer (11) & Primary \\
Nama_cabang & Varchar (64) & key \\
\hline
\end{tabular}

d. Tabel Transaksi

Table transaksi berisi tentang data Transaksi.

Tabel 4: Tabel Transaksi

\begin{tabular}{|l|l|l|}
\hline \multicolumn{1}{|c|}{ Field } & \multicolumn{1}{|c|}{ Type } & \multicolumn{1}{c|}{ Extra } \\
\hline Id_transaksi & Integer (11) & PK \\
No_transaksi* & Integer (11) & \\
Tanggal & Date & \\
Keterangan & Varchar (64) & \\
Jenis_akun & Varchar (30) & \\
Nominal & Decimal & \\
Id_user** & Integer (11) & FK \\
Id_cabang** & Integer (11) & FK \\
\hline
\end{tabular}

e. Tabel Jurnal

Tabel 5: Tabel Jurnal

\begin{tabular}{|l|l|l|}
\hline \multicolumn{1}{|c|}{ Field } & \multicolumn{1}{|c|}{ Type } & Extra \\
\hline Id_jurnal* & Integer (11) & PK \\
Tgl & Date & \\
Debit & Decimal & \\
Kredit & Decimal & \\
\hline
\end{tabular}

f. Tabel Laporan L/R (Laba/Rugi)

Table yang terakhir, adalah table Laporan. Yang mempunyai field sebagai berikut :

Tabel 6: Tabel Laporan Laba/Rugi

\begin{tabular}{|c|c|c} 
Field & Type & Extra
\end{tabular}




\begin{tabular}{|l|l|l|}
\hline Id_rl * & Integer(11) & PK \\
Bulan & Varchar (2) & \\
Tahun & Varchar (4) & \\
Mtetap & Decimal (10) & \\
Mttetap & Decimal (10) & \\
Mtotal & Decimal (10) & \\
Ktetap & Decimal (10) & \\
Kttetap & Decimal (10) & \\
Ktotal & Decimal (10) & \\
RL & Decimal (10) & \\
Keterangan & Varchar (64) & \\
Id_cabang & Integer (11) & \\
\hline
\end{tabular}

\section{IMPLEMENTASI SITEM LAPORAN KEUANGAN SEDERHANA}

Implementasi merupakan proses kelanjutan dari Rancangan Sistem yang telah dibuat. Implementasi juga merupakan suatu penerapan dan pengembangan dari rancanngan sistem yang telah dibuat, serta merupakan satu tahapan akhir dari proses Perancangan Sistem.

\subsection{Teknologi Pendukung Proses Implementasi}

Teknologi pendukung untuk proses implementasi sistem serta pengembangannya sangat dibutuhkan. Adapun teknologi pendukung yang digunakan untuk proses implementasi sistem ini, merupakan sebuah teknologi berbasis internet, yang dibangun dengan cara membuat sebuah web server pada Internet. Dan dalam pembuatannya, masih menggunakan web server lokal (localhost) dan menggunakan database server "AppServ". Dan menggunakan task phpMyAdmin untuk membangun database "lapdb". Di bawah ini adalah gambar dari halaman index untuk AppServ dan php Myadmin:

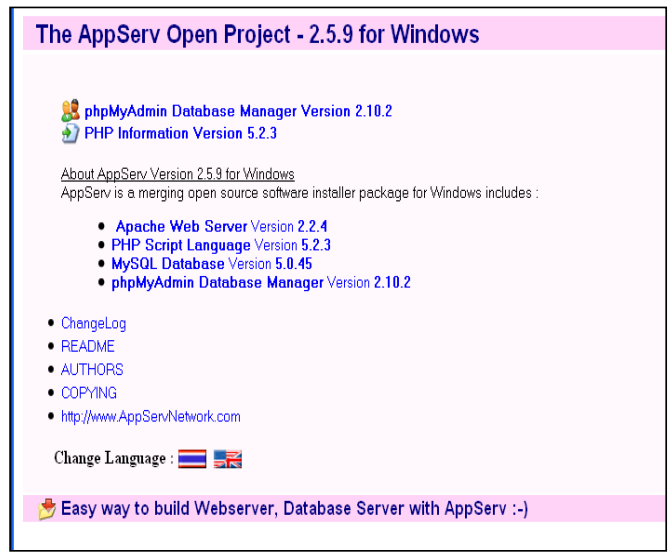

Gambar 6.1: Gambar Halaman Index untuk AppServ.

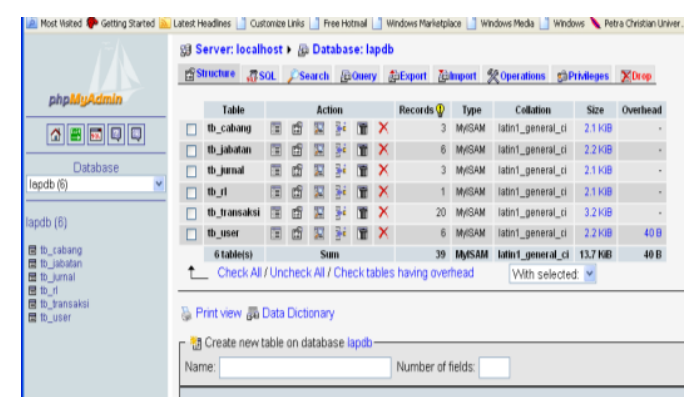

Gambar 6.2: Gambar Halaman phpMyAdmin yang digunakan untuk membangun database lapdb.

\subsection{Hasil Rancangan Sistem}

Hasil dari Rancangan sistem yang telah dibuat, dapat dijelaskan sebagai berikut :

a. Halaman Utama. 
Halaman utama merupakan halaman Index dari Laporan Keuangan Berbasis Web. Dimana pada halaman ini, disediakan menu untuk Login semua user berdasarkan jabatannya. Menu ini terdapat disebelah kiri dari halaman Index, seperti yang terlihat pada gambar di bawah ini :

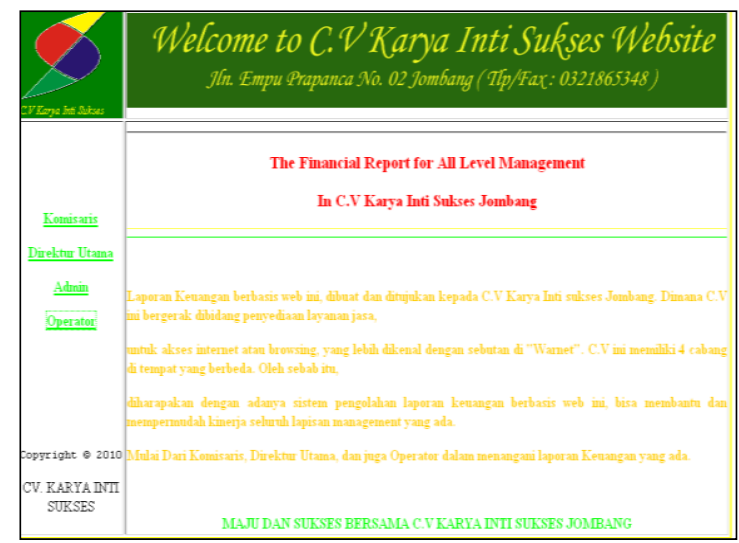

Gambar 6.3: Halaman Index Laporan Keuangan Berbasis Web

b. Form Login.

Sebelum menggunakan fasilitas yang ada pada Laporan Keuangan Berbasis Web, setiap user harus melakukan Login, dengan mengisi user name dan password sesuai dengan ketentuan yang ada.

Berikut adalah gambar form Login untuk semua user.

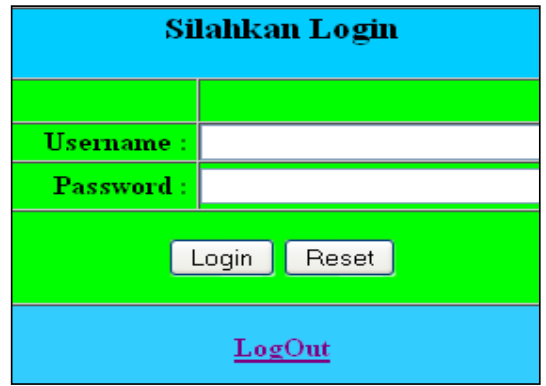

Gambar 6.4 : Form Login untuk User

Adapun kode program dari form Login di atas adalah :

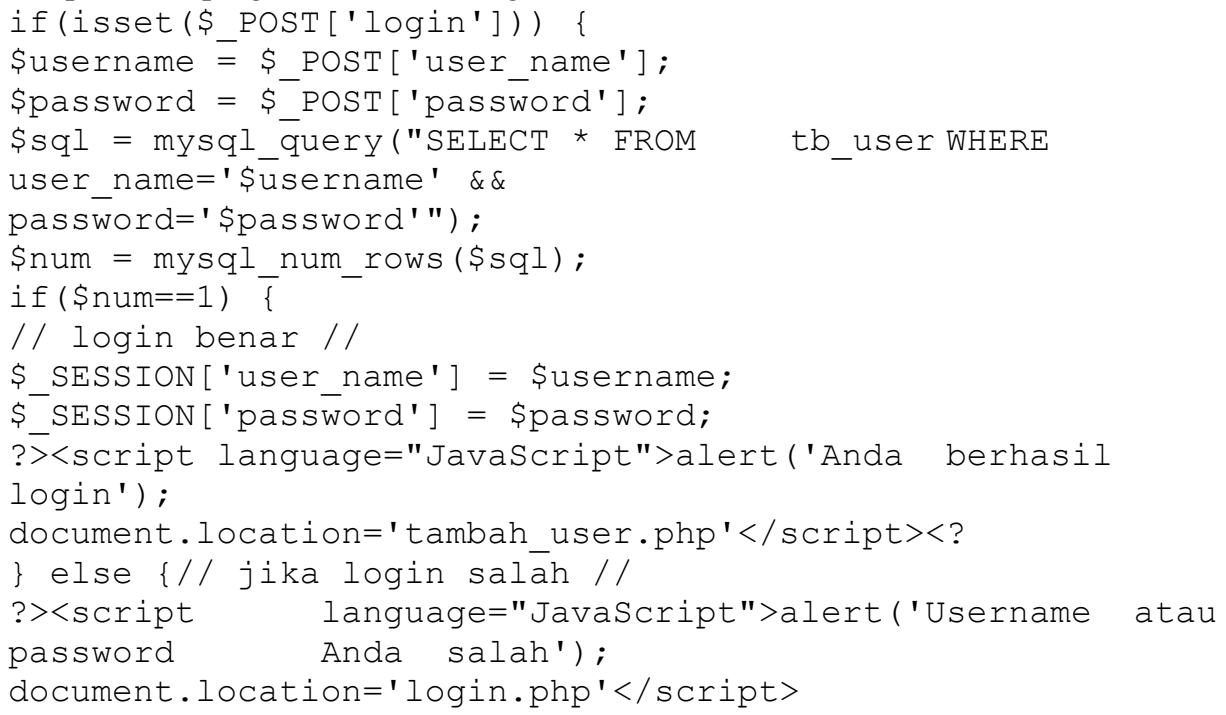


$<$ ?

Pada proses Login, username serta password yang dimasukkan disesuaikan dengan data yang ada di dalam tabel user. Ini ditunjukkan dengan perintah:

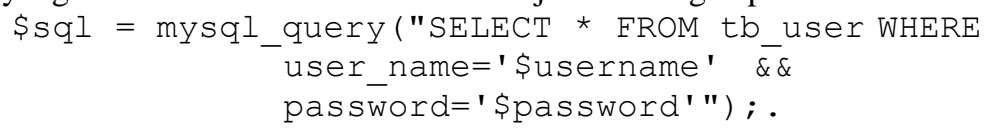

c. Halaman Index Untuk setiap user sesuai dengan jabatannya.

Setiap jabatan pada level manajemen, memiliki hak akses yang berbeda. Sehingga setiap lapisan manajemen memiliki bagian halaman antar muka yang berbeda. Berikut adalah salah satu gambar halaman tatap muka sesuai dengan jabatannya:

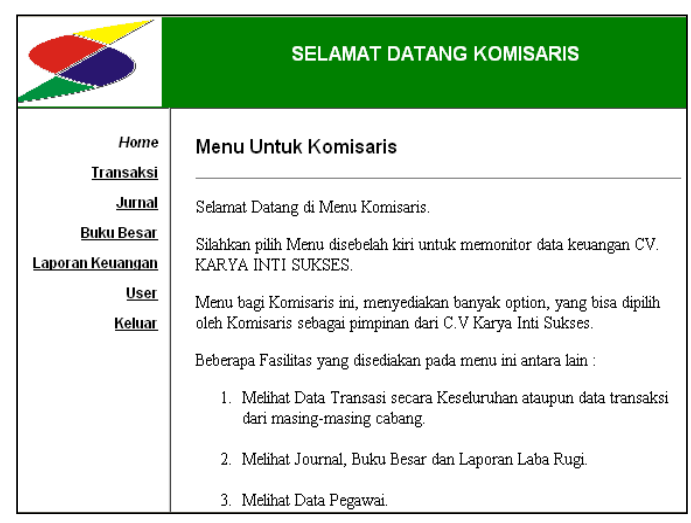

Gambar 6.5: Halaman Index untuk Komisaris

Dari halaman index dari masing-masing user, dapat dilihat pula hak akses dari user untuk memanfaatkan sistem yang ada. Misalnya : Komisaris. Sebagai oarang yang memiliki posisi tertinggi dalam level manajemen, Komisaris mempunyai hak akases untuk mengetahui setiap detail informasi yang ada pada sistem. Tetapi, Komisaris tidak memiliki hak akses untuk mengubah isi dari informasi yang ada pada sistem.

d. Menu yang disediakan untuk User.

Setiap user memiliki menu yang berbeda sesuai dengan posisinya dalam perusahaan. Misalnya: Direktur Utama, yang mempunyai hak akses penuh dalam hal controlling dan financial management dan bisa melakukan input, edit ataupun delete data yang ada pada sistem. Serta Operator yang bertugas untuk melakukan input laporan keuangan harian dan Admin yang bertugas untuk membuat, mengedit ataupun menghapus user account. Berikut adalah contoh menu untuk Direktur Utama:

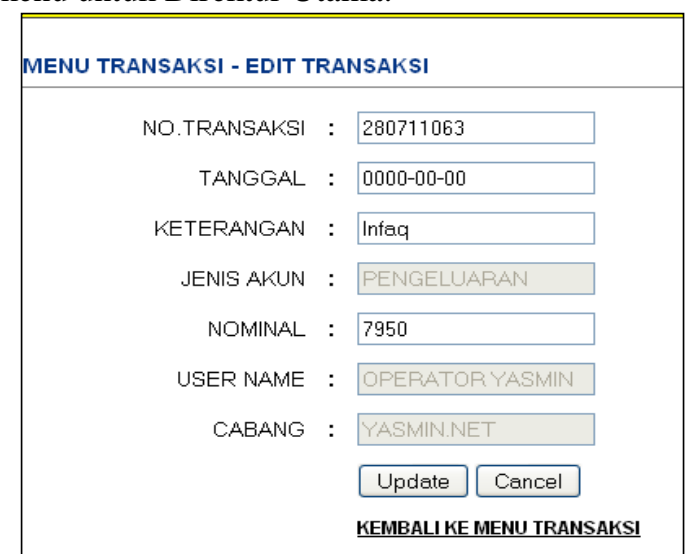

Gambar 6.6: Gambar Menu Edit Data Transaksi untuk Direktur Utama

Adapun data transaksi yang ditampilkan pada menu edit transaksi dipanggil dengan kode program sebagai berikut : 
\$query = "SELECT A.ID_TRANSAKSI, A.NO_TRANSAKSI, A.TANGGAL, A.KETERANGAN, A.JENIS_AKUN, A.NOMINAL, A.ID_USER,

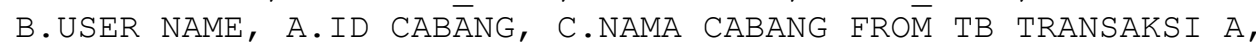

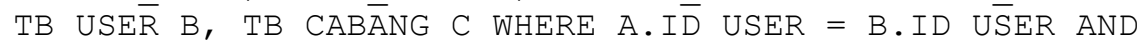

A. $\bar{I} D \_C A B A N G=-C \cdot I D \_C A B A N G$ AND A.NO_TRANSAKSI $=$

'\$notransaksi'"; .

Dari kode program dijelaskan bahwa hampir semua isi dari kolom transaksi diambil dari tb_transaksi, sedangkan nama cabang diambil dari tb_cabang dan user name dari tb_user.

e. Menu Tambah Data.

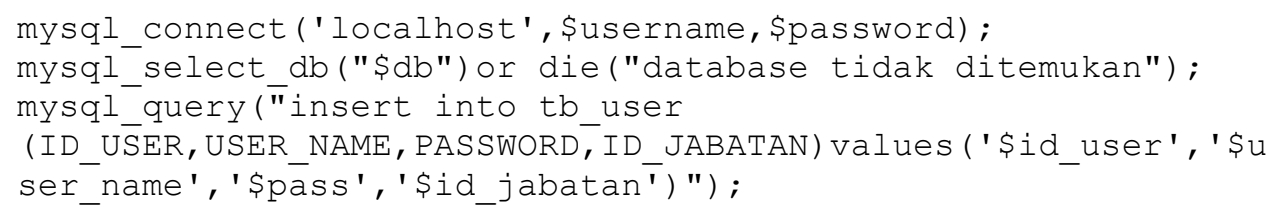

Perintah di atas merupakan perintah SQL yang digunakan untuk menambahkan data pada table yang sudah dibuat. Misalnya: data user yang akan ditambahkan pada table user, seperti kode program di atas. Tapi pada pemrograman PHP dan MySQL, perintah harus dipanggil pada antar muka untuk penambahan data dengan menggunakan script : form action $=$ “...”, yang disesuaikan dengan nama untuk file tambah data.

Di bawah ini adalah gambar form tambah/input data user:

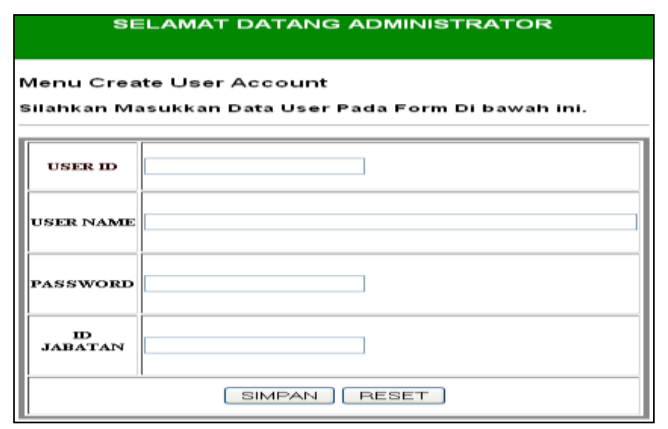

Gambar 6.7: Gambar Input Data User oleh Admin untuk menambah user.

f. Kode Program untuk Hapus Data

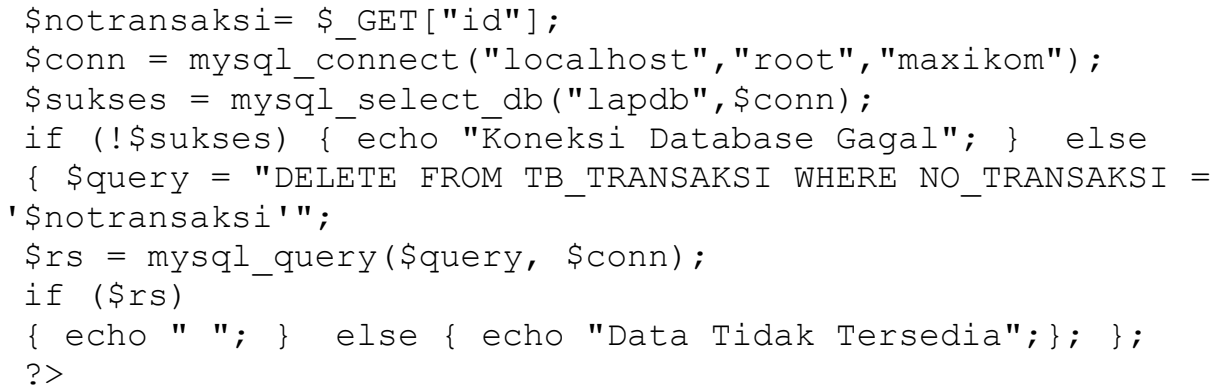

Kode di atas digunakan untuk menghapus data yang tersimpan pada table, misalnya : table transaksi. Penggunaannya pun sama dengan kode program untuk menambah data, yang harus dipanggil jika digunakan pada pemrograman PHP dan MySQL.

g. Menu Jurnal.

Menu jurnal digunakan untuk menampilkan data transaksi sesuai dengan batasan tanggal, bulan dan tahun yang bisa dipilih oleh pengguna. Di bawah ini adalah gambar dari antar muka untuk Menu Jurnal: 


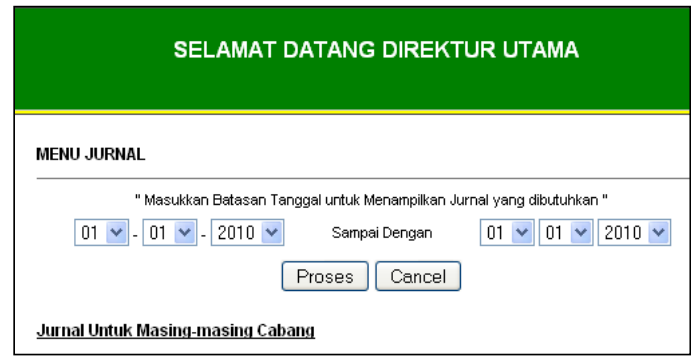

Gambar 6.8:Untuk menentukan batasan tanggal untuk menampilkankan jurnal dari transaksi.

Ketika user menekan tombol proses maka eksekusi program untuk tampil jurnal, akan dilakukan. Dan kode program untuk menentukan batasan tanggal adalah:"...... WHERE TANGGAL BETWEEN '\$thnmin/\$blnmin/\$tglmin' AND '\$thnmax/\$blnmax/\$tglmax'". Sedangkan kode program untuk mejumlahkan total debit dan kridit pada jurnal adalah : "....SUM(DEBIT) AS DEBIT, $\operatorname{SUM}(\operatorname{KREDIT}) \ldots \ldots . .$.

Gambar 6.9 : Gambar tampilan hasil

h. Menu Buku Besar

Pada menu buku besar Akun Pemasukkan dan Pengeluaran dipisahkan. Dan pembuatan buku jurnal ditentukan berdasarkan bulan dan tahun, yang kemudian diproses dan ditampilkan hasilnya. Di bawah ini adalah gambar menu buku besar:

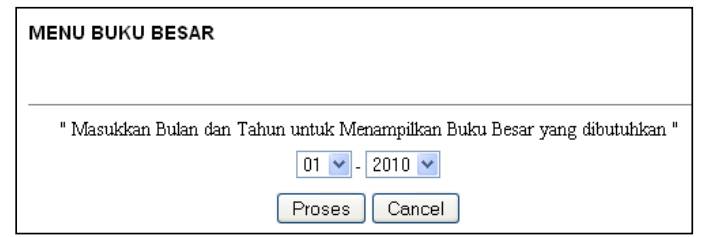

Gambar 6.10: Gambar Tampilan Buku Besar

Adapun kode program untuk menentukan batasan bulan dan tahun pada hasil dari Buku Besar adalah:

\$query="SELECT ID TRANSAKSI, NO TRANSAKSI, TANGGAL,

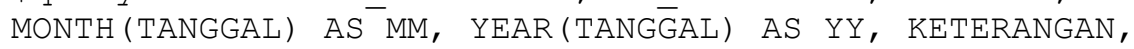
JENIS AKUN, NOMINAL AS DEBIT, 0 AS KREDIT FROM TB TRANSAKSI WHERE $($ JENIS AKUN = 'PEMASUKAN') AND (MONTH $($ TANGGĀL $)=\$ \mathrm{bln})$ AND (YEAR (TAN̄GGAL) = \$thn) ORDER BY TANGGAL";

Kode program di atas berfungsi untuk menampilkan isi dari kolom: no transaksi, tanggal, keterangan, jenis akun dan nominal untuk debit dan kredit dari tabel transaksi. Sedangkan untuk mengetahui saldo dari akun pengeluaran dan pemasukkan digunakan kode program sebagai berikut:

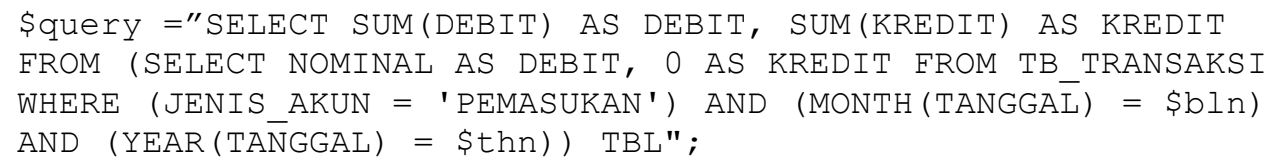


Gambar hasil dari perhitungan untuk Buku Besar adalah:

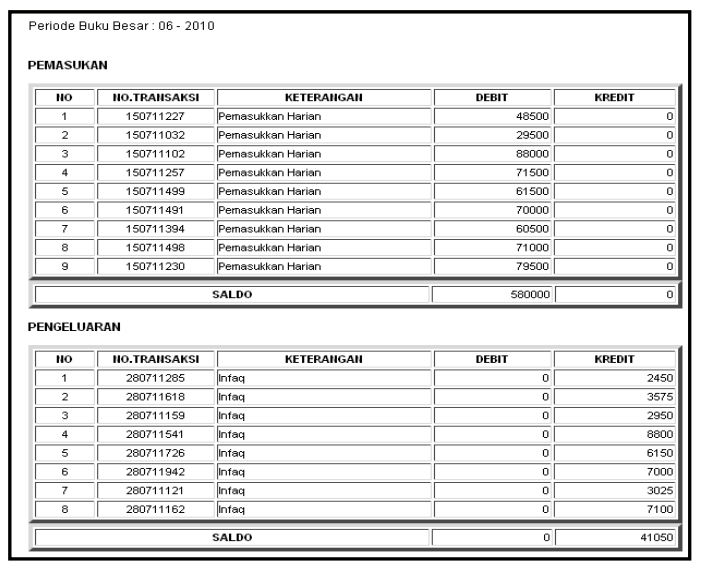

Gambar 6.11: Gambar Hasil Buku Besar

i. Menu Laporan Rugi Laba.

Menu ini berfungsi untuk mengetahui laporan laba rugi dari C.V Karya Inti Sukses. Hasilnya bisa diketahui dengan cara menjumlahkan semua pendapatan dan dikurangi dengan semua pengeluaran. Berikut ini adalah tampilan antar muka untuk Laporan Laba Rugi:

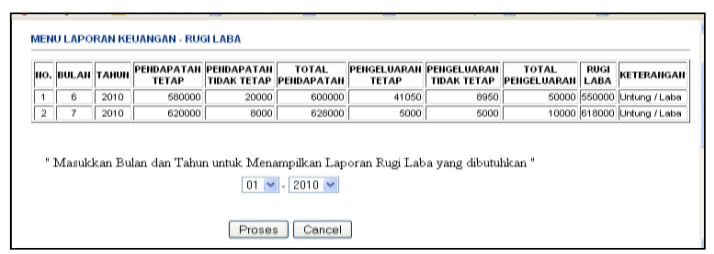

Gambar 6.12: Halaman awal Laporan Laba Rugi.

Setelah tombol proses ditekan, maka eksekusi program dilakukan. Selanjutnya untuk isi pada pendapatan tetap akan diambil dari jumlah total akun pemasukkan pada bulan dan tahun yang telah dipilih. Begitu juga dengan isi dari pengeluaran tetap yang diambil dari total semua pengeluaran, berdasarkan batasan bulan dan

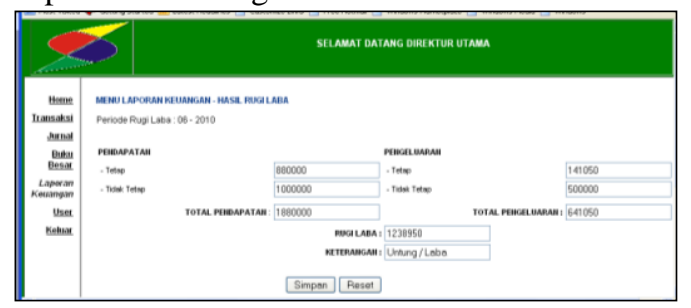
tahun yang dipilih. Kemudian hasilnya akan ditampilkan pada halaman kedua. Di bawah ini adalah gambar halaman kedua dan kode programnya:

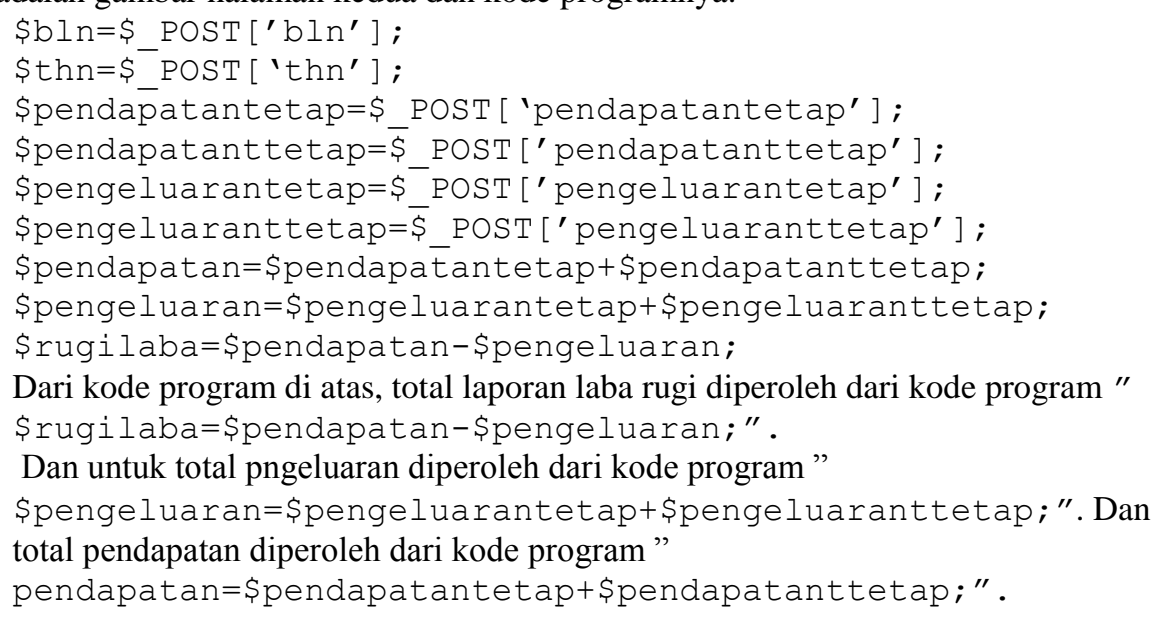

Adapun gambar dari proses hitung dan simpan laporan rugi laba adalah: 


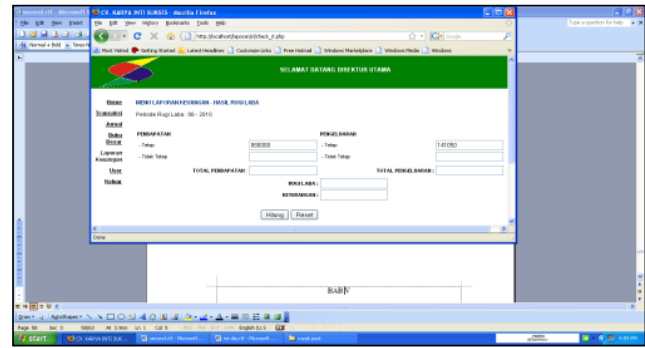

Gambar 6.13: halaman untuk hitung Laporan Laba Rugi.

Gambar 6.14: Halaman untuk menyimpan hasil dari perhitungan Laporan Rugi Laba

\section{DAFTAR PUSTAKA}

Firdaus, PHP dan MySQL dengan DREAMWEAVER, Maxikom, Palembang 2007.

Kadir, Abdul, Dasar Pemrograman Web Dinamis Menggunakan PHP, Andi Yogyakarta, Yogyakarta 2001.

Nugroho, Bunafit, Database Relasional Dengan MySQL, Andi Offset, Yogyakarta 2005.

Nugroho, Bunafit, PHP Profesional, Andi Yogyakarta, Andi Yogyakarta, Yogyakarta 2007.

Peranginangin, Kasiman, Aplikasi WEB Dengan PHP dan MySQL, Andi Yogyakarta, Yogyakarta 2006.

Prasetyu, Eko, Pemrograman WEB PHP dan MySQL, Graha Ilmu, Gresik 2008.

Simarmata, Janner, Perancangan Basis Data, Andi Yogyakarta, Medan 2007.

Wahyono, Teguh, Memahami Pemrograman Web dengan PHP dan MySQL dalam 24 jam, Gava Media, Yogyakarta 2005.

http://adboclass.files.wordpress.com/2010/03/modul-1.pdf, diakses pada tanggal 29 Maret 2010.

http://agustin.staf.gunadarma.ac.id/Downloads/files/11387/Jurnal+\&+Posting. Doc, diakses pada tanggal 20 Juli 2010.

http://blog.re.or.id, diakses pada tanggal 29 maret 2010.

http://claudiapaskah.ngeblogs.com/pengantar-bisnis/, diakses pada tanggal 07 April 2010.

http://dasar-akuntansi.blogspot.com/2009/09/jurnal-dasar-dasar-akuntansi.html, diakses pada tanggal 20 Juli 2010.

http://irfunk.multiply.com/jurnal/item/30, diakses pada tanggal 07 April 2010.

http://nugrohotech.wordpress.com/2007/06/29/diagram-arus-data-\%E2\%80\%93-dad-data-flowdiagram-\%E2\%80\%93-dfd/,

diakses pada tanggal 29 Maret 2010. 
http://repository.binus.ac.id/content/F0642/F064256873.ppt, diakses pada tanggal 20 Juli 2010.

http://pdfdatabase.com/download/perancangan-sistem-informasi-doc-15833611.html, diakses pada tanggal 29 maret 2010.

http://terbaru2010.com/ilmu-komputer-pengertian-database-cara-membuat-database.html, diakses pada tanggal 29 Maret 2010. 